\title{
Screening and Phytochemical Analysis of Some Plants Extracts against Aflatoxin Producing Fungi in Sesame, Benue State, Nigeria
}

\author{
M. Elaigwu1 ${ }^{*}$, H. O. A. Oluma², C. U. Aguoru², A. Onekutu ${ }^{3}$ \\ ${ }^{1}$ Department of Integrated Science, College of Education, Oju, Nigeria \\ ${ }^{2}$ Department of Botany, Federal University of Agriculture, Makurdi, Nigeria \\ ${ }^{3}$ Department of Zoology, Federal University of Agriculture, Makurdi, Nigeria \\ Email: ^elaigwumatthew1986@gmail.com
}

How to cite this paper: Elaigwu, M., Oluma, H.O.A., Aguoru, C.U. and Onekutu, A. (2020) Screening and Phytochemical Analysis of Some Plants Extracts against Aflatoxin Producing Fungi in Sesame, Benue State, Nigeria. American Journal of Plant Sciences, 11, 344-353.

https://doi.org/10.4236/ajps.2020.113025

Received: February 6, 2020

Accepted: March 20, 2020

Published: March 23, 2020

Copyright (๑) 2020 by author(s) and Scientific Research Publishing Inc. This work is licensed under the Creative Commons Attribution International License (CC BY 4.0).

http://creativecommons.org/licenses/by/4.0/

\begin{abstract}
This study investigated the phytochemical screening of some plant extracts against aflatoxin producing fungi in sesame (Sesamum indicum). The plants are Prosopis africana, Psorospermum febrifugum and rhizome of Curcuma longa. Various parts of the plants were dried, grounded and extracted in methanolic solvent. The preliminary phytochemical screening of methanol extracts for stem bark, leaves and rhizome of Curcuma longa revealed the presence of saponins, flavonoids, steroids, cardiac, glycosides, terpenoids, phenols and tannins. The result of anti-aflatoxigenic activity indicates that methanol extracts of these plants show significant activity against the fungi isolates. The effect of plants extracts on mycelia growth of the test organism reduced the mycelia growth significantly as compared to the control (Plate 6 (a-f)). In view of the efficacy of the activity of the plant extracts, it could be concluded that these medicinal plants possess antifungal properties that can be exploited for the control of aflatoxin in sesame. Further works are needed to investigate the biological active ingredients of these plants.
\end{abstract}

\section{Keywords}

Aspergillus spp, Plant Extracts, Aflatoxin, Phytochemical Analysis

\section{Introduction}

Sesamum indicum L. commonly called Beniseed in the country and international circle is one of the oldest oilseeds cultivated in Nigeria [1]. Beniseed has been reported to be an excellent source of high quality oil and protein [1]. The seed contains about $50 \%$ edible semi-drying oils and also is rich in protein, carbohy- 
drate, calcium and phosphorus [1]. Based on its chemical composition, Beniseed therefore is a crop of considerable value. However, Sesame seed has the risk of contamination during storage by mycotoxins, especially the ubiquitous and hepatotoxic aflatoxins which are produced when seeds are kept under conditions that favour the development of these fungi [2]. Aflatoxins are potent toxic, carcinogenic, mutagenic, immunosuppressive and teratogenic agents produced as secondary metabolites by Aspergillus flavus [3]. A study on the nature of the toxin suggested its origin from the fungus Aspergillus flavus and thus, the toxin was named "aflatoxin" by virtue of its origin from A. flavus [4]. Aflatoxins have been reported to be highly toxic to humans and animals, causing liver diseases and cancer, and chronic exposure to aflatoxins is also associated with stunting and immune system suppression [5] [6].

Chemical and physical approaches are widely used to minimize the risk of aflatoxin contamination in food [7]. These strategies are usually expensive, time-consuming, inefficient and also reported to cause serious environmental and health problems [8]. The most promising strategy currently being used to reduce pre-harvest contamination of crops with aflatoxin is to introduce non-aflatoxin (biocontrol) A. flavus into the crop environment. There are many challenges facing this strategy. First, the population biology of $A$. flavus is not well understood due to $A$. flavus's diversity, its ability to form heterokaryotic reproductive forms, and its unknown ability to survive for prolonged periods after application. Secondly, biocontrol strains must be selected that are suitable for the environment, the type of crop, and the soil into which they will be introduced.

The African continent holds an enormous resource in terms of floral biodiversity and its medicinal plants have remained a main reservoir of phytochemicals for pharmaceutical drug development [9]. Plants produce secondary metabolites that can inhibit bacteria, fungi, viruses and pests [10]. All parts or any single part of the plant, such as bark, leaves, peel, seed, and stem, may possess antimicrobial properties. Plants produce secondary metabolites that can inhibit bacteria, fungi, viruses and pests [10]. This justifies the search for an alternative source of control which could inhibit the establishment of aflatoxin, producing potential fungi, the plant derived extracts. Research results on the efficacy of plant extracts to control toxigenic strains of $A$. flavus are scanty and several plants exist in North-Central Nigeria whose extracts with antifungal activity have been reported [11].

The medicinal plants used for this study are: Prosopis africana, Psorospermum febrifugum and Curcuma longa L. Almost all parts of the tree of Prosopis africana are used in medicine; the leaves in particular are used for the treatment of headache and toothache as well as various other head ailments [12]. The roots are a diuretic and are used to treat gonorrhea, tooth and stomach-ache, dysentery and bronchitis [12]. Psorospermum febrifugum is widely used in traditional medicine in Africa, being employed in the treatment of a wide range of conditions but especially those related to fevers and skin problems. This species has 
been used as a febrifuge, a leprosy treatment, a poison antetode, a purgative [13]. The Roots bark decoction is also recorded to be effective for the treatment of Syphilis [14].

Curcuma longa L. is a rhizomatous herbaceous evergreen plant. The rhizome, the portion of the plant used medicinally, is usually boiled, cleaned, and dried, yielding a yellow powder. Dried Curcuma longa is the source of the spice turmeric, the ingredient that gives curry powder its characteristic yellow colour. Apart from its culinary uses, turmeric has been used widely in the traditional medicine in India, Pakistan, and Bangladesh because of its several beneficial properties [15]. Turmeric is anti-inflammatory to the mucous membrane which coats the throat, lungs, stomach and intestine [16]. The objective of the present investigation is therefore to screen these plants for fungicidal activity against aflatoxin producing fungi in Sesame in Makurdi, Benue State, North Central Nigeria.

\section{Materials and Methods}

\subsection{Collection and Identification of Plant Materials}

The plant materials were collected from Makurdi Local government Area of Benue state, Nigeria. Fresh leaves and stem barks of both Psorospermum febrifugum and Prosopis africana were harvested from the field while rhizome of Curcuma longa was purchased from railway market in Makurdi town. Using polythene bags, the plant leaves, stem barks of the plants and Curcuma longa L. were labeled properly before taken to the laboratory for further processing. Taxonomic identification of the plant samples were confirmed and authenticated by Dr. Namadi Sunusi in the Department of Botany, Faculty of Science, Ahmadu Bello University Zaria where Voucher Specimen numbers were given as Prosopis africana 0900251, Curcuma longa (Turmeric) 06281 and Psorospermum febrifugum 0936. Herbarium specimens was deposited and preserved in the Herbarium collection of the Department of Botany, Federal University of Agriculture Makurdi, Benue State.

\subsection{Preparation of Plant Materials}

The collected plant materials were initially rinsed with distilled water to remove soil and other contaminants. The stem-barks were cut into smaller pieces, the leaves were shade dried for a week and then grounded into powder by mortar and pestle. The rhizome was boiled in water at $100^{\circ} \mathrm{C}$ for 30 minutes. This is necessary before drying to enable the turmeric to be cured. Boiling the roots soften them and remove the raw odour. They were later cut into smaller pieces, cleaned, dried and grounded into fine powder. The powder was prepared using suitable standard sieves. The samples were kept inside bottles to carry out the extraction process and for further analysis.

\subsection{Methods of Extraction}

Extraction was done using Soxhlet extraction as described by Abah and Egwari 
[17] with slight modification. Twenty $(20 \mathrm{~g})$ grams each of the powdered plant was weighed using a digital weighing scale (Labtech. BL 2001) and dispensed into the extraction thimble and $200 \mathrm{mls}$ of appropriate Methanol (ME) which was measured using a measuring Cylinder and poured into the round bottom flask. The apparatus was set up on heating mantle and the temperature was adjusted to match the boiling point of the solvent being used. The process was allowed to run for 4 hours. After the extraction, the extract was concentrated using a rotary evaporator. The concentrated extract was transferred into bijou bottles and stored in the refrigerator at $4^{\circ} \mathrm{C}$ for phytochemical analysis and anti-fungi screening.

\subsection{Isolation of Fungi}

\subsubsection{Media Preparation}

Sabouroud Dextrose Agar (SDA) was used throughout the study. Sixty five (65 g) grams of SDA was suspended in $1000 \mathrm{ml}$ of distilled water. SDA was supplemented with Chloramphenicol $\left(500 \mathrm{mg} / \mathrm{L}^{-1}\right)$ to prevent bacterial contamination. The mixture was stirred till the SDA was completely dissolved and autoclaved at $121^{\circ} \mathrm{C}$ for 15 minutes. According to manufacturer's description, the media was composed of Mycological peptone (10.00 gram/litre), Agar 15.00, Dextrose (40.00 gram/L), $\mathrm{PH}(5.6 \pm 0.2)$ at $25^{\circ} \mathrm{C}$ and Agar (15.00 gram/litre)

\subsubsection{Isolation of Fungi by Direct Plating Method}

The method described by Jha [18] Agar plate method was used for the isolation of fungi. All the samples (Sesame seeds) were surface sterilized by dipping them in $78 \%$ of alcohol for $1 \mathrm{~min}$ and then rinsed in several changes of sterile distilled water. About six seeds of a sample taken at random were placed in each of the petri-dishes containing Sabouraud Dextrose Agar (SDA) and chloramphenicol (500 mg. $\mathrm{L}^{-1}$ ) with the aid a sterile forceps. The dishes were incubated at $27^{\circ} \mathrm{C} \pm$ $2^{\circ} \mathrm{C}$ for 3 - 5 days.

\subsubsection{Preparation of Pure Culture}

Pure cultures of the pathogens were obtained by sub-culturing method. The materials used includes: Cork borer, ethanol, mounted needle, inoculums and spirit lamp. The cork borer was dipped in ethanol and placed in the busen flame briefly to allow the ethanol burn off. The cork borer was then used to cut a core of mycelium from the edge of the colonies growing from the plated root tissues on Sabouroud Dextrose Agar (SDA) medium. The lid of petridish containing sterile Sabouroud Dextrose Agar (SDA) medium was partially lifted and the fungal mycelium was placed on to the centre of the sterile Agar medium with the aid of a mounted needle which had been flamed in the ethanol and incubated for fungi growth at $28^{\circ} \mathrm{C}$.

\subsubsection{Fungal Identification}

The Sub cultured fungi were primarily identified using cultural and morphologica (colony colour, surface texture) and microscopic characteristics (Nature of 
spore, conidiophores, sporangiophore, and vessicles) using identification keys by [19] [20] [21].

\subsubsection{Effect of Plant Extracts on Mycelia Growth of Aflatoxigenic Fungi} The effect of the plant extracts for anti aflatoxic fungi was carried out to test the inhibitory action of the extracts on the test fungi. The poisoned food method was used in the preliminary screening of methanolic extracts for their antifungal properties evaluation. First, the mycelia growths were evaluated in $90 \mathrm{~mm}$ Petri dishes filled with SDA solid medium amended with $20 \%$ solvent extracts of each plant. Next, the center of each Petri dish was inoculated with $5 \mathrm{~mm}$ diameter disc of fungal mycelium, taken from pure culture ( 7 days old). The petridish without plant extract served as control. Then, all inoculated dishes were incubated at $25^{\circ} \mathrm{C} \pm 2{ }^{\circ} \mathrm{C}$ for 6 days (plates A-F). Three replicates were maintained for each treatment. Colony diameter of the test fungus in treatment and control set was measured and antifungal activity was calculated in terms of mycelia inhibition following the method of Kurma et al. [21].

\subsubsection{Preliminary Phytochemical Screening of the Plant Extracts}

Phytochemical screening of the plant extracts was carried out by a procedure that was based on those earlier reports by [22] [23] [24].

\section{Results}

\section{Effects of Plant Extracts on Aflatoxigenic Fungi (Table 1)}

Effects of methanolic extract on the isolates shows that Curcuma longa L. has reputed value for its antifungal properties. Among the different plant extracts, Curcuma longa extract brought about the lowest radial growth of all the organisms evaluated and it was significantly different from the growth observed on samples treated with $P$. africana (leaf), $P$. febrifugum (leaf), $P$. africana (stem bark) and $P$. febrifugum (stem bark) extracts showing highly statistical significant level $(P<0.01)$ Curcuma longa has the lowest mean of (10.00), P.africana leaf (12.50) P. africana stem bark (11.83), P. febrifugum (Leaf) (16.33), P. febrifugum (Stem bark) (15.50) respectively (Plate 6 (a-f)).

Table 1. Preliminary methanolic screening of the plant extracts.

\begin{tabular}{cccccc}
\hline $\begin{array}{c}\text { Phytochemical } \\
\text { Constituent }\end{array}$ & $\begin{array}{c}\text { Curcuma } \\
\text { longa }\end{array}$ & $\begin{array}{c}\text { Leaf of } P \text {. } \\
\text { africana }\end{array}$ & $\begin{array}{c}\text { Stem of } \\
\text { P. africana }\end{array}$ & $\begin{array}{c}\text { Leaf of } \\
\text { P. febrifugum }\end{array}$ & $\begin{array}{c}\text { Stem of } \\
\text { P. febrifugum }\end{array}$ \\
\hline Saponins & + & + & + & + & + \\
Flavonoids & + & + & + & + & + \\
Steroids & - & + & + & - & - \\
Cardiac Glycosides & + & + & - & - & - \\
Terpenoids & + & + & + & + & + \\
Phenol & + & + & + & + & + \\
Tannins & + & + & + & + & + \\
\hline
\end{tabular}

NB: += positive; = Negative. 


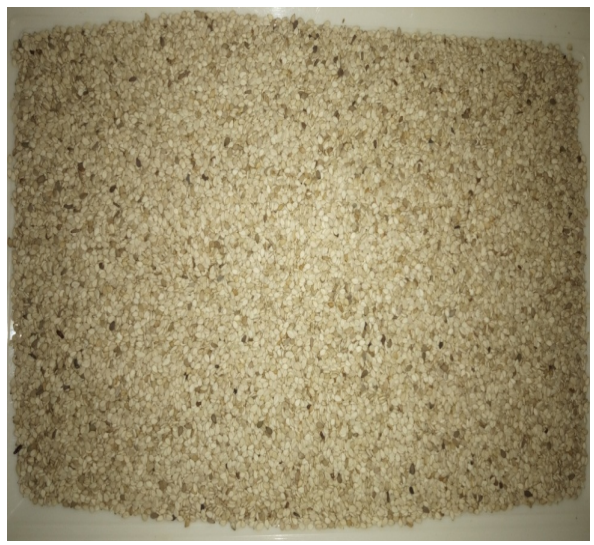

Plate 1. Raw Sesame samples.

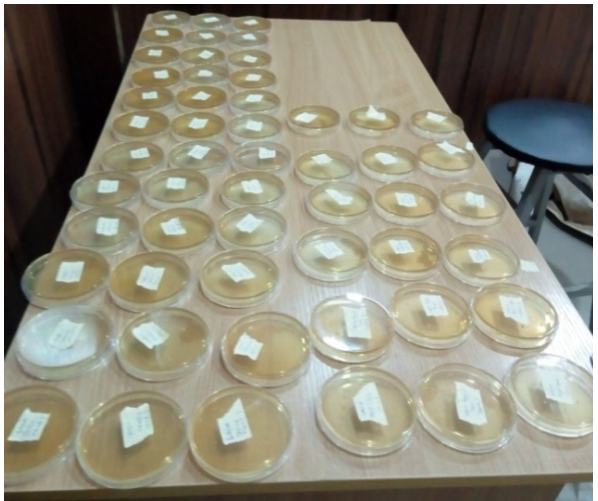

Plate 2. Innoculation of sesame seeds for fungi growth.

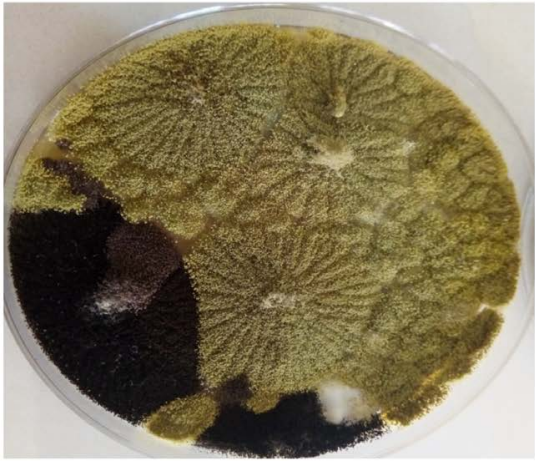

(a)

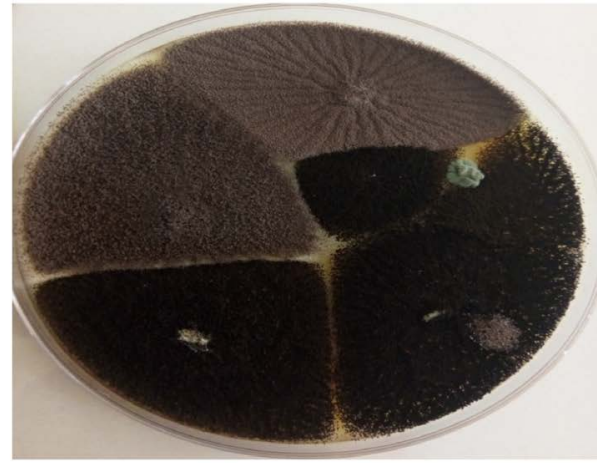

(b)

Plate 3. (a), (b). Growth of Fungi colonies.

\section{Discussion and Conclusion}

Many researches have been conducted to demonstrate the effects of different plants against pathogenic fungi. In this present investigation, the anti aflatoxigenic activity of the methanolic plant extracts of Curcuma longa L. (Turmeric), stem bark of Prosopis africana, leaf of $P$. africana, Stem bark of Psorospermum febrifugum and leaf of Psorospermum febrifugum were assayed against toxigenic 


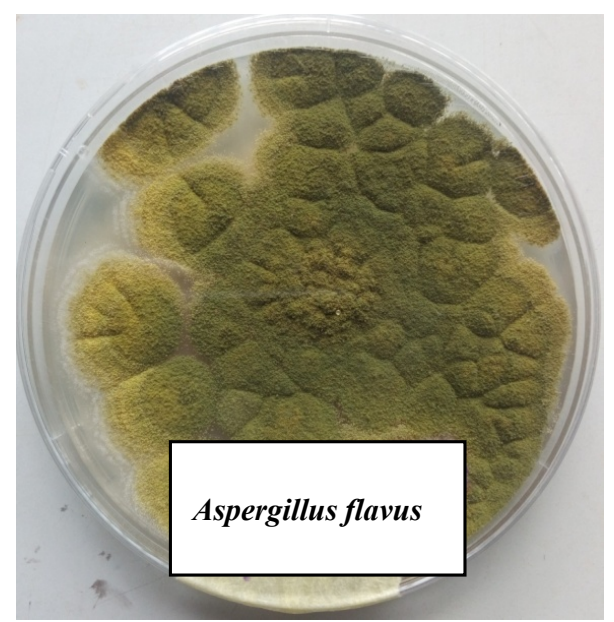

Plate 4. Pure culture of Aspergillus flavus.

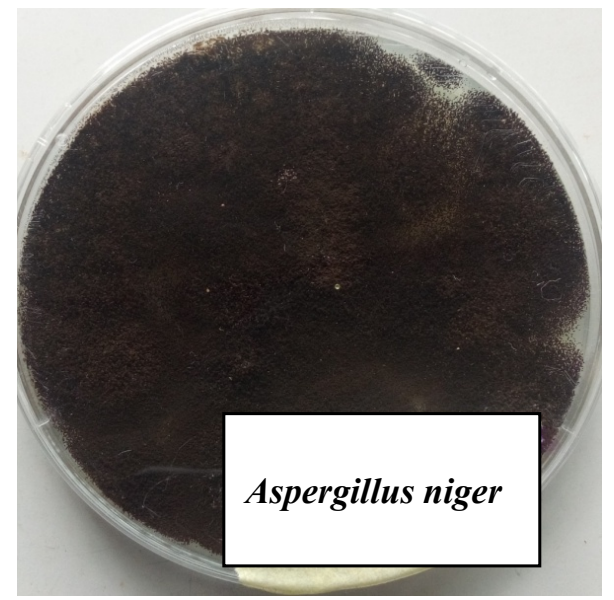

Plate 5. Pure culture of Aspergillus niger.

A. flavus and A. niger in sesame production. All the methanolic extracts of the plants showed promising activity against the test fungi. This indicates their broad range of activity (Plate $6(\mathrm{a}-\mathrm{f})$ ). This is consistent with the earlier reports that many plant products contain fungitoxic constituents that have the potential to control plant diseases [25] [26] [27]. It was reported that Curcuma longa has anti-inflammatory, choleretic, antimicrobial, and carminative actions [28]. Similarly, Paramasivan et al., [29] reported that in vitro studies with Turmeric showed that it has strong antimicrobial properties.

Kisangau [30] observed that series of xanthones were isolated from P. febrifugum and are responsible for its antiviral activities and other constituents from the extracts were proven to be effective as antimicrobial agents. Methanol extracts of $P$. africana leaves were reported to have substantial antifungal activity against mycelia growth of the fungus Colletotrichum musae, causing the most serious post harvest fungal diseases of banana [31]. Many studies have demonstrated a strong correlation between the phenolic/antioxidant compounds of plants and their antifungal/antiaflatoxigenic activities [32]. Consequently, plants 

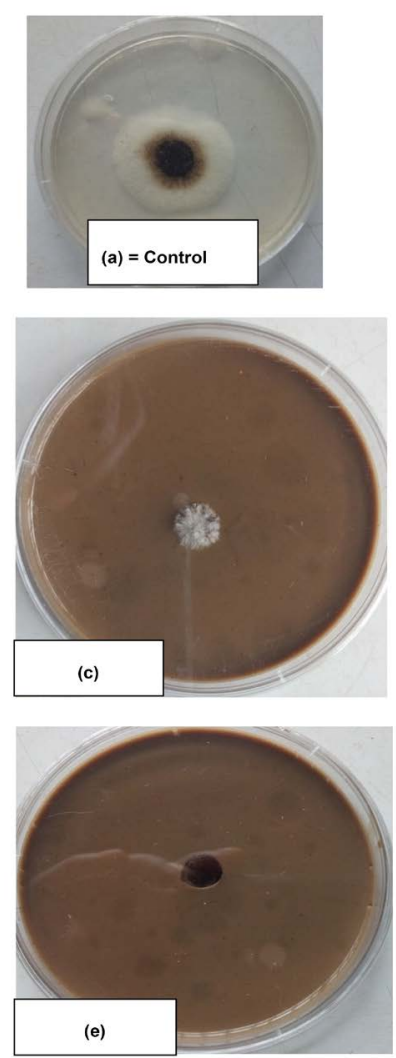

(e)
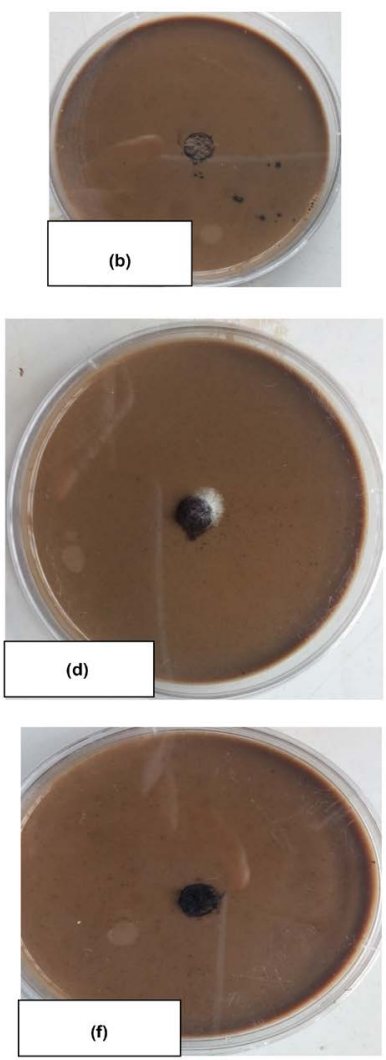

(f)

Plate 6. Inhibitory effect of plant extracts on mycelia growth of aflatoxigenic fungi.

extracts could potentially provide protection against aflatoxigenic fungus and aflatoxins. Previously, many plant extracts have been investigated for their capacity to inhibit aflatoxin production not only in culture medium conditions but also in food commodities [11] [33]. Particularly, Equisetum arvense, Stevia rebaudiana, Zingiber officinalis, Oxalis corniculata and Trigonella foenum-graecum have been reported to have antifungal and antiaflatoxigenic properties [11] [33].

It is suggested that more and more indigenous plants should be exploited for the prevention of aflatoxin because of its concern all over the world. This present study is significant in identification of indigenous plant extracts as possible detoxifier and biocontrol for aflatoxigenic fungi. These findings can be exploited for the prevention of aflatoxin contamination in sesame. Further works are needed to investigate the biologically active ingredients of these plants.

\section{Conflicts of Interest}

The authors declare no conflicts of interest regarding the publication of this paper.

\section{References}

[1] Adagba, M.A., Shokalu, O., Amosun, A. and Ochigbo, A.A. (2009) Recommended 
Practices for Beniseed Production. National Cereals Research Institute, Badeggi, Bida, Nigeria, 2-5.

[2] Makun, H.A., Apeh, D.O., Adeyemi, H.R.Y., Nagago, T., Okeke, J.O., Mustapha, A.S. and Oyinloye, B.A. (2014) Determination of Aflatoxin in Sesame, Rice, Millet and Acha Using HPLC. Chemical Journal transactions, 3,1516-1524.

[3] Krishnamurthy, Y.L. and Shashikala, J. (2006) Inhibition of Aflatoxin B Production of Aspergillus flavus, Isolated from Soybean Seeds by Certain Natural Plant Products. Letters in Applied Microbiolog, 43, 469-474. https://doi.org/10.1111/j.1472-765X.2006.02011.x

[4] Bennet, J.W. (2010) An Overview of the Genus Aspergillus. In: Machida, M. and Gomi, K., Eds., Aspergillus Molecular Biology and Genomics, Caister Academic Press, Norfolk, UK, 1-17.

[5] Sahil, V.P., Tejas, C.B., Hiren, N.B., Pratibha, S. and Abhay, K. (2015) Aflatoxins: Causes \& Effects. Agricultural and Biological Sciences, 13, 148.

[6] Kumar, V.V. (2018) Aflatoxins: Properties, Toxicity and Detoxification. International Journal of Nutrition \& Food Science, 6, Article ID: 555696.

https://doi.org/10.19080/NFSIJ.2018.06.555696

[7] Tian, F. and Chun, H.S. (2017) Natural Products for Preventing and Controlling Aflatoxin Contamination of Food. InTech, London. https://doi.org/10.5772/intechopen.68413

[8] Pal, K.K. and Gardener, B.M. (2006) Biological Control of Plant Pathogens. The Plant Health Instructor, 2, 1117-1142. https://doi.org/10.1094/PHI-A-2006-1117-02

[9] Kurmar, V. and Vasisht, K. (2004) Compendium of Medicinal and Aromatic Plants. Volume 1. ICS-UNIDO, Trieste, Africa.

[10] Kalpna, D.R. and Sumitra, V.C. (2013) Fighting Multidrug Resistance with Herbal Extracts, Essential Oils and Their Components.

https://www.sciencedirect.com/topics/pharmacology-toxicology-and-pharmaceutic al-science/plant-extract

[11] Krsihna, R.V., Srinivas, M. and Akarapu, R.R. (2011) Plant Extracts in the Management of Aflatoxin Production by Aspergillus Flavus. International journal of Pharma and Biosciences, 2, 492-498.

[12] Ezike, A.C., Akah, P.A., Okoli, C.O., Udegbunam, S., Okwume, N., Okeke, C. and Iloani, O. (2010) Medicinal Plants Used in Wound Care: A Study of Prosopis africana (Fabaceae) Stem Bark. Indian Journal of Pharmaceutical Science, 72, 3349. https://doi.org/10.4103/0250-474X.70479

[13] Francesco, E., Serena, F. and Salvatore, J.G. (2013) Phytochemistry and Pharmacognosy of the Genus Psorospermum. Phytochemistry, 12, 673-684. https://doi.org/10.1007/s11101-013-9274-8

[14] Jiofack, T., Fokunang, C. Guedje, N., Kemeuze, V., Fongnzossie, E., Nkongmeneck, B.A., Mapongmetsem, P.M. and Tsabang, N. (2010) Ethnobotanical Uses of Medicinal Plants of Two Ethnoecological Regions of Cameroon. International Journal of Medicine and Medical Sciences, 2, 60-79.

[15] Rahul, K.V., Preeti, K., Rohit, K.M., Vijay, K., Verma, R.B. and Rahul, K.S. (2018) Medicinal Properties of Turmeric (Curcuma longa L.): A Review. International Journal of Chemical Studies, 6, 1354-1357.

[16] Roshan, P.Y. and Gaur, T. (2017) Versatility of Turmeric: A Review the Golden Spice of Life. Journal of Pharmacognosy and Phytochemistry, 6, 41-46.

[17] Abah, S.E. and Egwari, L.O. (2014) Methods of Extraction and Ant Microbial Sus- 
ceptibility Testing of Plant Extract. African Journal of Basic Applied Sciences, 3, 205-209.

[18] Jha, D. (1995) Laboratory Manual on Seed Pathology. Vikas Publishing House, New Delhi, India, 7-9.

[19] Davise, H. (2002) Important Fungi. A Guide to Identification. 4th Edition, American Society for Microbiology Press, Washington DC, 1-111.

[20] Klich, M. (2002) Identification of Common Aspergillus Species. Utrech. Central Bureeau Voor Schimmel Cultures, The Netherlands, 116.

[21] Kurma, S., Shekhar, M., Ali, K.A and Sharma, P. (2007) A Rapid Technique for Detection of Toxigenic and Non-Toxigenic Strain of Aspergillus flavus from Maize Grain, India. Phytopathology, 1, 31-34.

[22] Harborne, J.B. (1973) Phytochemical Methods. Chapman and Hall Ltd., London, 49-188.

[23] Trease, G.E. and Evans, W.C. (1983) Pharmacognosy Magazine. 12th Edition, Bailliere Tindal, London.

[24] Sofowora, A. (1993) Medicinal Plants and Traditional Medicinal in Africa. 2nd Edition, Sunshine House, Ibadan, Nigeria, 134-156.

[25] Enikuomehin, O.A. and Peters, O.T. (2002) Evaluation of Crude Extracts from Some Nigerian Plants for the Control of Field Diseases of Sesame (Sesamum indicum L.). Tropical Oilseeds Journal, 7, 84-93.

[26] Oluma, H.O.A. and Garba, I.U. (2004) Screening of Eucaptus Globules and Ocimum gratissimum against Pithium aphanidermatum. Nigerian Journal of Plant Protection, 21, 109-114.

[27] Amadioha, A.C. and Obi, V.I. (1999) Control of Anthracnose Disease of Cowpea by Cympopogon citratus and Ocimum gratissimum. Acta Phytopathologica et Entomologica Hungarica, 34, 85-89.

[28] Mills, S and Bone, K. (2000) Principles and Practice of Phytotherapy. Churchill Livingstone, Toronto, ON, 100-129.

[29] Paramasivam, S., Thangaradjou, T. and Kannan, L. (2007) Effect of Natural Preservatives on the Growth of Histamine-Producing Bacteria. Journal of Environmental Biology, 28, 271-274.

[30] Kisangau, D.P., Herbert, V.M., Ken, M. and Cosam, C. J. (2007) Use of Traditional Medicines in the Management of HIV/AIDS Opportunistic Infections in Tanzania: A Case in the Bukoba Rural District. Journal of Ethnobiology and Ethnomedicine, 3, 29. https://doi.org/10.1186/1746-4269-3-29

[31] Bazie, S., Ayalew, A. and Woldetsadik, K. (2014) Antifungal Activity of Some Plant Extracts against Colletotrichum musae the Cause of Postharvest Banana Anthracnose. Journal of Plant Pathology and Microbiology, 5, 1-4. https://doi.org/10.4172/2157-7471.1000226

[32] Sova, M. (2012) Antioxidant and Antimicrobial Activities of Cinnamic Acid Derivatives. Mini-Reviews in Medicinal Chemistry, 12, 749. https://doi.org/10.2174/138955712801264792

[33] Garcia, A., Rhoden, S.A., Bernardi Wenze, J., Orlandelli, R.C., Azevedo, J.I. and Pamphile, J.A. (2012) Antimicrobial Activity of Crude Extracts of Endophytic Fungi Isolated from Medicinal Plant Sapindus saponaria L. Journal of Applied Pharmaceutical Sciences, 2, 35-40. https://doi.org/10.7324/JAPS.2012.21007 